\title{
Studi Simulasi Pola Operasi Bukaan Pintu Bendung Gerak Mrican (Waru Turi) Kecamatan Gampangrejo Kabupaten Kediri Jawa Timur
}

\section{Favian Giffary Ramadian ${ }^{1 *}$, Rini Wahyu Sayekti ${ }^{1}$, Dian Sisinggih $^{1}$}

\author{
${ }^{1}$ Jurusan Teknik Pengairan, Fakultas Teknik, Universitas Brawijaya, \\ Jalan MT. Haryono No. 167, Malang, 65145, INDONESIA \\ *korespondensi email: faviangiffary@gmail.com
}

\begin{abstract}
Waru Turi Weir is one of the largest motion weirs in Brantas River. That weir irrigates Waru area of 12,710 hectares and Turi area of 16,444 hectares. Main function from weir is to manage water (irrigation requirment) and flood control structures. From a total of nine spillway gates, only eight gates are operating optimally. With the irrigation requirment water that must be fulfilled. The opening gate operation pattern refers to the Normal Water Level at an elevation of +57.3 meters as the ideal reference. The water level receded in elevation of +57.2 meters and the floods in elevation +58.28 meters. A method of simulated opening the gate (spillway) and gate intake based on irrigation requirements. By the gate opening simulation method, maximum discharge of the spillway door $(+57.3 \mathrm{~m})$ is $63.67 \mathrm{~m} 3 / \mathrm{s}$, with an opening of 2.73 meters per door (a total of eight functioning gates). While at the Waru intake the discharge is 6.211 $\mathrm{m} 3 / \mathrm{s}$ and Turi with a discharge of $7.936 \mathrm{~m} 3 / \mathrm{s}$, the maximum gate opening is 0.3 meters per door. With the new operating pattern, the discharge that flows at each intake gate still meets the irrigation requirment discharge.
\end{abstract}

Keywords: Motion Weir, Normal Water Level, Sluice Gate

Abstrak: Bendung Gerak Mrican (Waru Turi) merupakan salah satu bendung gerak terbesar yang membendung Sungai Brantas. Bendung mengairi daerah irigasi Waru seluas $12.710 \mathrm{Ha}$ dan daerah irigasi Turi seluas 16.444 Ha. Fungsi utama bendung adalah sebagai pemenuhan kebutuhan air irigasi (pengontrol debit) dan bangunan pengendali banjir. Dari total sembilan pintu spillway hanya delapan pintu yang beroperasi secara maksimal. Dengan kebutuhan air irigasi yang harus tetap terpenuhi, maka diperlukan pola operasi baru untuk tetap menunjang irigasi tersebut. Pola operasi bukaan pintu mengacu pada elevasi Muka Air Normal/Normal Water Level pada elevasi +57,3 meter sebagai acuan ideal. Muka air surut 
pada elevasi +57,2 meter, dan Muka Air Banjir pada elevasi +58,28 meter. Metode simulasi bukaan pintu (intake maupun pintu spillway) didasarkan dengan kebutuhan irigasi. Dengan metode simulasi bukaan pintu didapatkan debit maksimal pintu spillway $(+57,3 \mathrm{~m})$ sebesar $63,67 \mathrm{~m}^{3} / \mathrm{det}$, dengan bukaan 2,73 meter tiap pintu (total delapan pintu yang berfungsi). Sedangkan pada pintu intake Waru debit sebesar $6,211 \mathrm{~m}^{3} /$ det dan Turi dengan debit 7,936 $\mathrm{m}^{3} / \mathrm{det}$ besar bukaan pintu maksimal 0,3 meter tiap pintunya. Dengan pola operasi baru, debit yang mengalir pada tiap pintu intake tetap memenuhi kebutuhan debit irigasi.

Kata kunci: Bendung Gerak, Muka Air Normal, Pintu Tegak

\section{Pendahuluan}

Ekosistem DAS dibagi daerah hulu, tengah dan hilir. Daerah hulu pada daerah aliran sungai mempunyai posisi yang sangat krusial untuk ketersediaan air pada daerah tengah maupun hilir. Daerah ini perlu dijaga ketersediaan air dari segi kualitas maupun kuantitas [1]. Berdasarkan pola pengelolaan sumberdaya air wilayah sungai Brantas merupakan wilayah sungai terbesar kedua di Pulau Jawa (Jawa Timur). Luas Daerah Aliran Sungai Brantas seluas $11.800 \mathrm{~km} 2$ dan total panjang sungai $320 \mathrm{~km}$ yang mencakup $25 \%$ luas provinsi Jawa Timur atau 9\% luas Pulau Jawa [2].

Bendung Gerak Mrican (Waru Turi) merupakan salah satu bendung yang ada pada Sungai Brantas. Fungsi bendung adalah untuk mengontrol debit agar kebutuhan air irigasi tetap terpenuhi. Terdapat dua intake pada Bendung Gerak Mrican, yaitu intake kiri (Waru) dan intake kanan (Turi) [3]. Pintu pada spillway dan intake merupakan pintu tegak (sluice gate). Dikarenakan usia pakai, pada pintu spillway hanya berfungsi delapan pintu dari total sembilan pintu. Hal ini mengakibatkan fungsi pintu spillway tidak berjalan secara maksimal [4]. Dengan kebutuhan debit irigasi yang harus tetap terpenuhi dari pintu intake dan pintu spillway, maka diperlukan pola operasi baru dengan total delapan pintu spillway [5].

\section{Metode Penelitian}

\subsection{Lokasi Studi}

Bendung Gerak Mrican (Waru Turi) terletak pada daerah aliran Sungai Brantas bagian hulu, tepatnya pada wilayah Desa Gampeng kecamatan Gampangrejo Kabupaten Kediri. Bendung gerak mengairi daerah irigasi Warujayeng seluas $12.710 \mathrm{Ha}$ (intake kiri), Daerah Irigasi Turi Tunggorono dan Daerah Irigasi Papar Peterongan seluas 16.444 Ha (intake kanan).

Panjang bendung sebesar 159,80 meter dengan lebar bendung 74,50 meter (termasuk apron) [6]. Dengan jenis bendung gerak pintu tegak (sluice gate) mempunyai sembilan (9) pintu spillway, dan empat (4) pintu intake Waru maupun intake Turi. Pintu spillway memiliki lebar 13,20 meter dan tinggi 3,85 meter. Sedangakan untuk intake Waru memiliki lebar pintu 3,60 meter dan tinggi 2,20 meter. Berbeda dengan pintu intake Waru, pintu intake Turi memiliki lebar 4,60 meter dengan tinggi pintu yang sama dengan pintu intake 
Waru [7]. Tampak atas denah Bendung Gerak Mrican (Waru Turi) disajikan pada Gambar 1 .

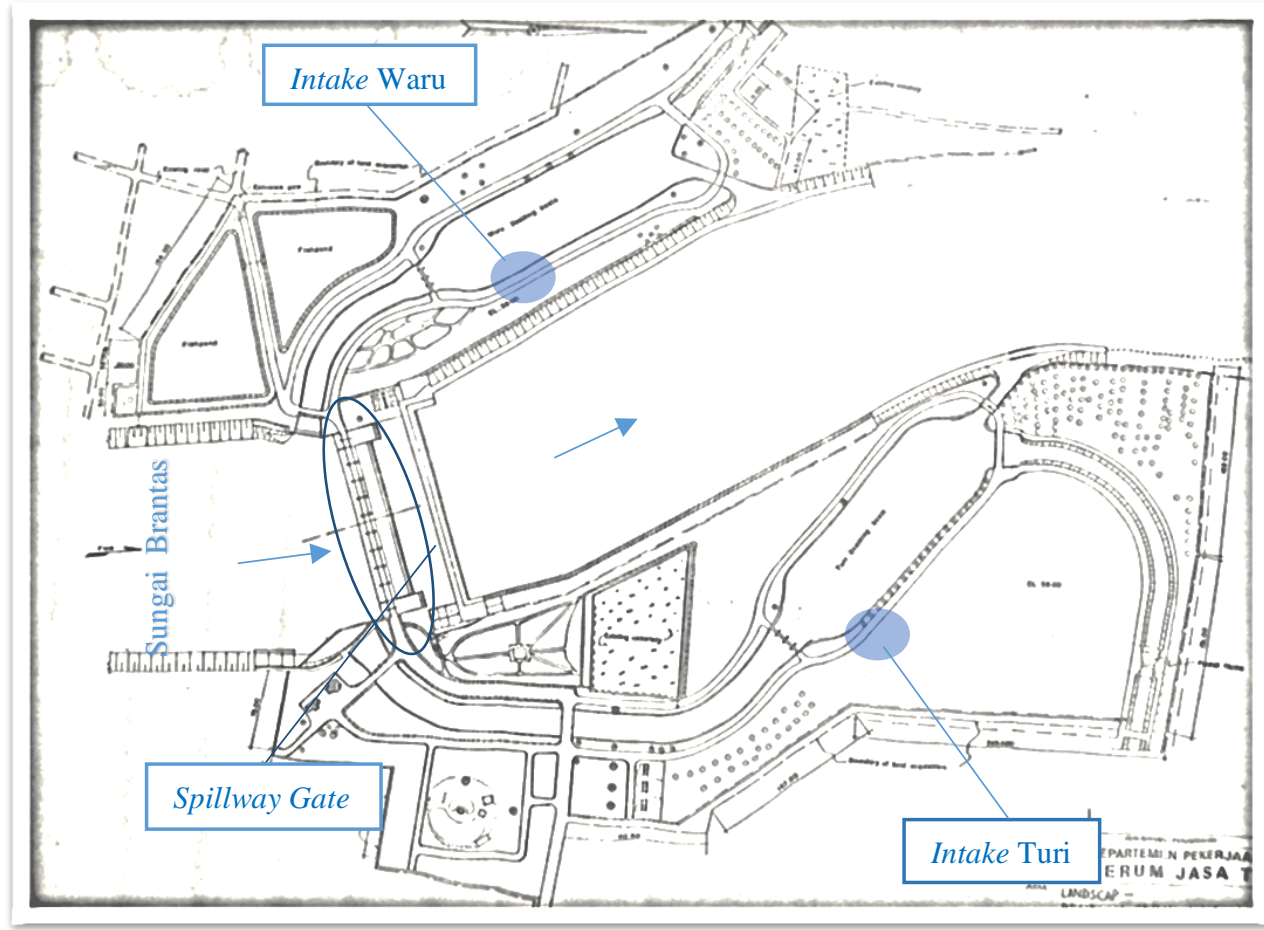

Gambar 1: Tampak Atas Bendung Gerak Mrican

\subsection{Metode}

Metode yang dilakukan dalam penulisan ini menggunakan metode simulasi bukaan pintu [8]. Perhitungan debit pada pintu mengacu pada tinggi muka air yang ditetapkan, muka air normal/MAN $(+57,3 \mathrm{~m})$, muka air surut/LWL $(+57,2 \mathrm{~m})$, dan muka air banjir/HWL $(+58,28 \mathrm{~m})$. Idealnya tinggi muka air normal yang dipakai dalam pengaplikasian dalam bendung. Namun jika terjadi kondisi-kondisi tertentu, memakai acuan muka air surut atau muka air banjir [9].

Perhitungan debit melalui pintu menggunakan rumus pada buku Andrew L. Simons. Rumus digunakan untuk mengatahui keluaran debit karena tinggi bukaan pintu. Perhitungan tinggi muka air mengacu pada debit sungai yang masuk pada bukaan pintu.

Debit keluaran pintu yang didapatkan dengan perhitungan Andrew L. Simons, kemudian di simulasikan dengan kebutuhan air irigasi pada intake Waru dan intake Turi. Pola operasi bukaan pintu menggabungkan bukaan pintu spillway, intake Waru, dan intake Turi. Dengan tetap memakai acuan MAN sebagai kondisi ideal. Untuk perumusan lebih detail dapat dilihat pada sub bab 2.3 [10]. 


\subsection{Persamaan}

Data tinggi muka air didapat dengan perhitungan debit yang lewat melalui bukaan pintu. Dari ilustrasi Gambar 2 dapat diketahui notasi $H_{0}, a, H_{l}$ yang nantinya dibuat untuk mencari nilai Q (debit) terhadap bukaan pintu.

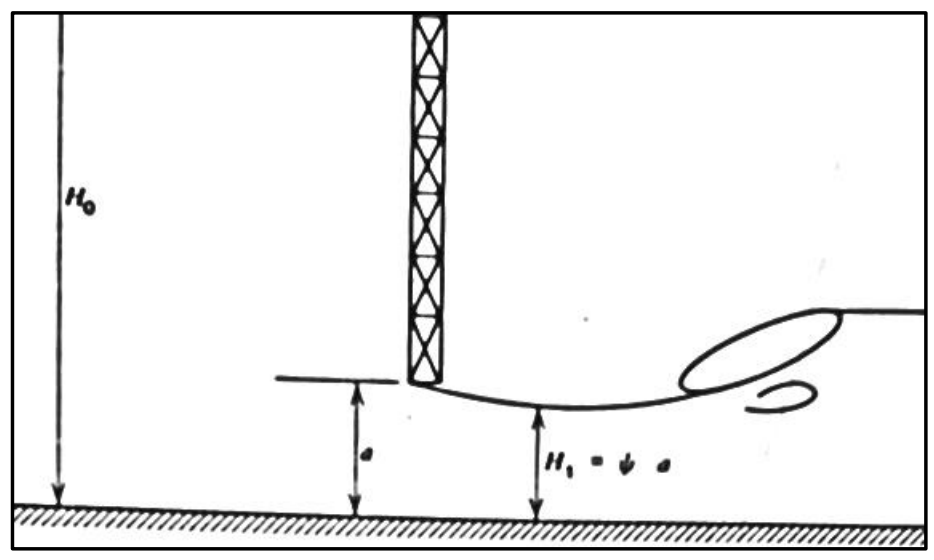

Gambar 2: Ilustrasi Aliran Pada Sluice Gate

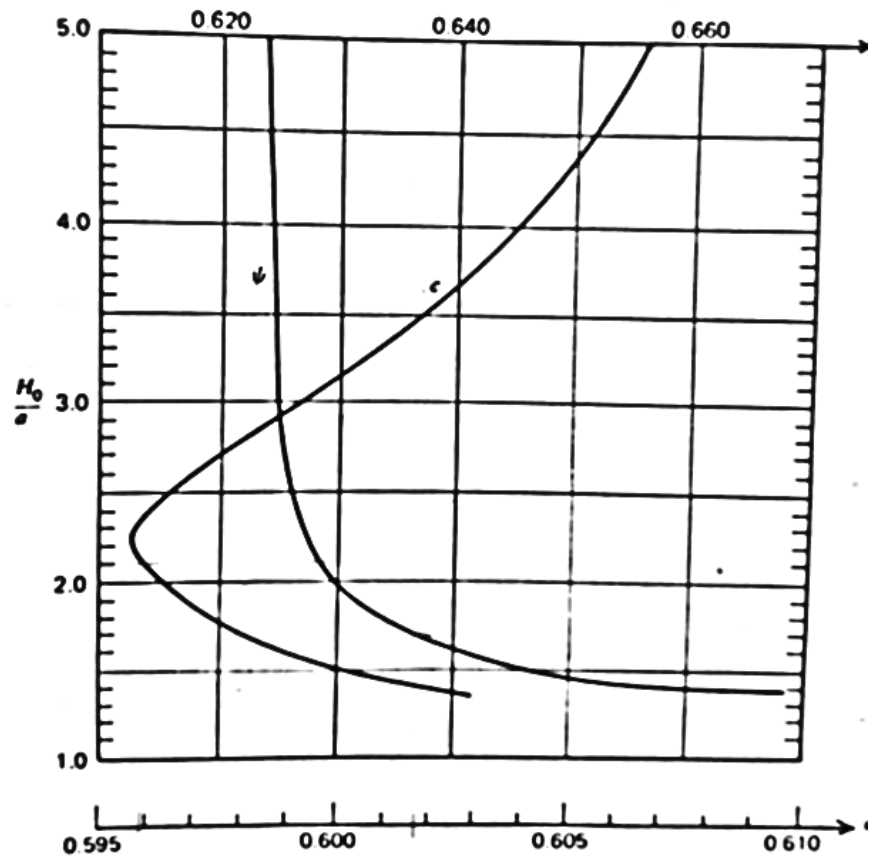

Gambar 3: Grafik Hubungan Nilai $H_{0} / a$ Dengan $\psi, c$

Grafik diatas menunjukkan nilai $H_{0} / a$ pada garis vertikal, dan lengkung nilai $a$ dan lengkung nilai $c$ pada garis horizontal. Nilai $\psi$ didapat dari percobaan yang bergantung pada nilai $H_{0} / a$. Dengan grafik tersebut dapat diketahui nilai $c$ dan $\psi$ berdasarkan nilai perbandingan tinggi muka air di hulu $\left(H_{0}\right)$ dan tinggi bukaan pintu $(a), H_{0} / a$ [10]. Dengan melihat rumus $H_{1}$ dengan variabel $\psi$ dan $a$, maka dapat digabungkan dalam persamaan sebagai berikut: (ilustrasi aliran pada gambar 2) 


$$
Q=b a c \sqrt{2 g} \frac{H_{0}}{\sqrt{H_{0}+\psi \cdot a}} \quad \text { Pers. } 1
$$

Dimana,

$\mathrm{Q}=$ Debit melalui lubang sluice gate $\left(\mathrm{m}^{3} / \mathrm{det}\right)$

$\mathrm{b} \quad=$ lebar pintu sluice gate $(\mathrm{m})$

$c=$ nilai koefisien debit (didapat dari grafik pada Gambar 3)

$\mathrm{g}=$ gravitasi $\left(9,81 \mathrm{~m} / \mathrm{det}^{2}\right)$

$H_{0}=$ kedalaman air pada hulu sebelum melewati pintu (m)

$\psi=$ nilai $\psi$ dapat dilihat pada grafik hubungan nilai $H_{0} / a($ Gambar 3$)$

$a \quad=$ tinggi bukaan pintu sluice gate (m)

\section{Hasil dan Pembahasan}

\subsection{Hasil Perhitungan Debit Melewati Sluice Gate}

Dari hasil perhitungan debit dengan bukaan pintu didapatkan tinggi muka air pada tiap pintu. Dimensi tiap pintu berbeda sesuai dengan perencanaan. Dibawah digambarkan kurva hubungan tinggi muka air dengan tinggi bukaan pintu dari hasil perhitungan. Ada tiga kurva sesuai dengan pintu intake Waru; pintu intake Turi; dan pintu spillway. Garis vertikal menunjukkan elevasi tinggi muka air; garis horizontal menunjukkan besaran debit (Q) karena bukaan pintu; dan kurva berwarna menunjukkan pengaruh besaran bukaan pintu terhadap debit dan tinggi muka air. Untuk lebih jelasnya dapat dilihat berikut ini:

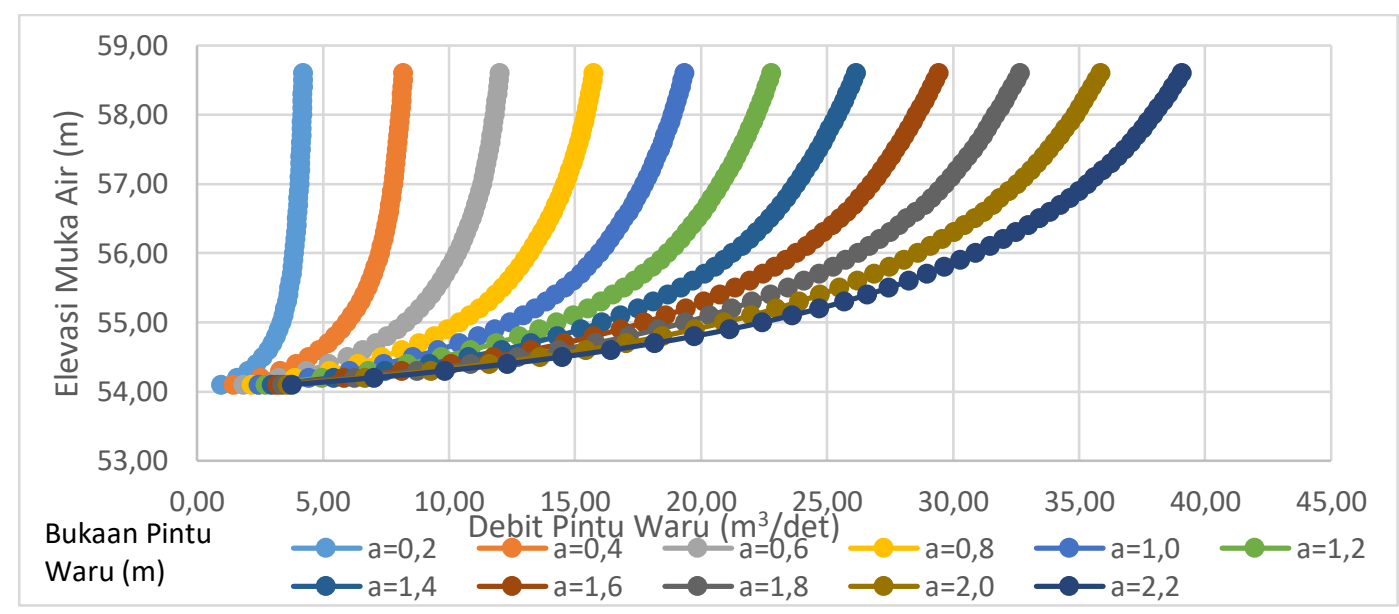

Gambar 4: Grafik Tinggi Muka Air dengan Tinggi Bukaan Pintu (Waru) 


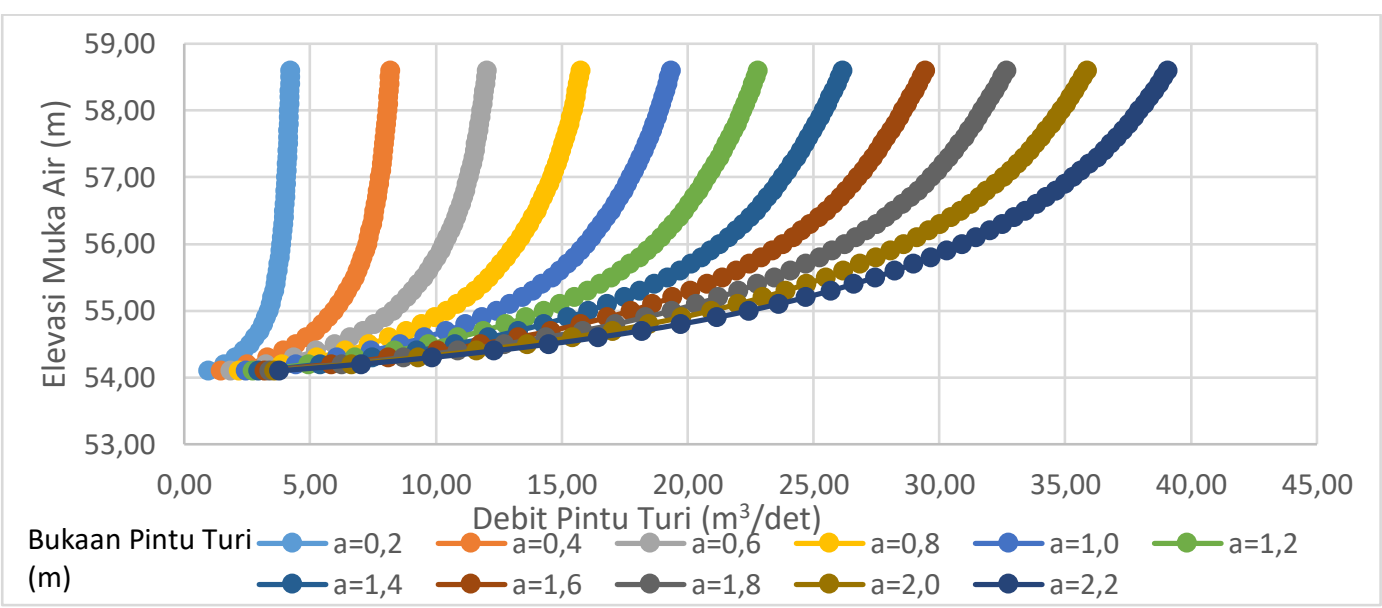

Gambar 5: Grafik Tinggi Muka Air dengan Tinggi Bukaan Pintu (Turi)

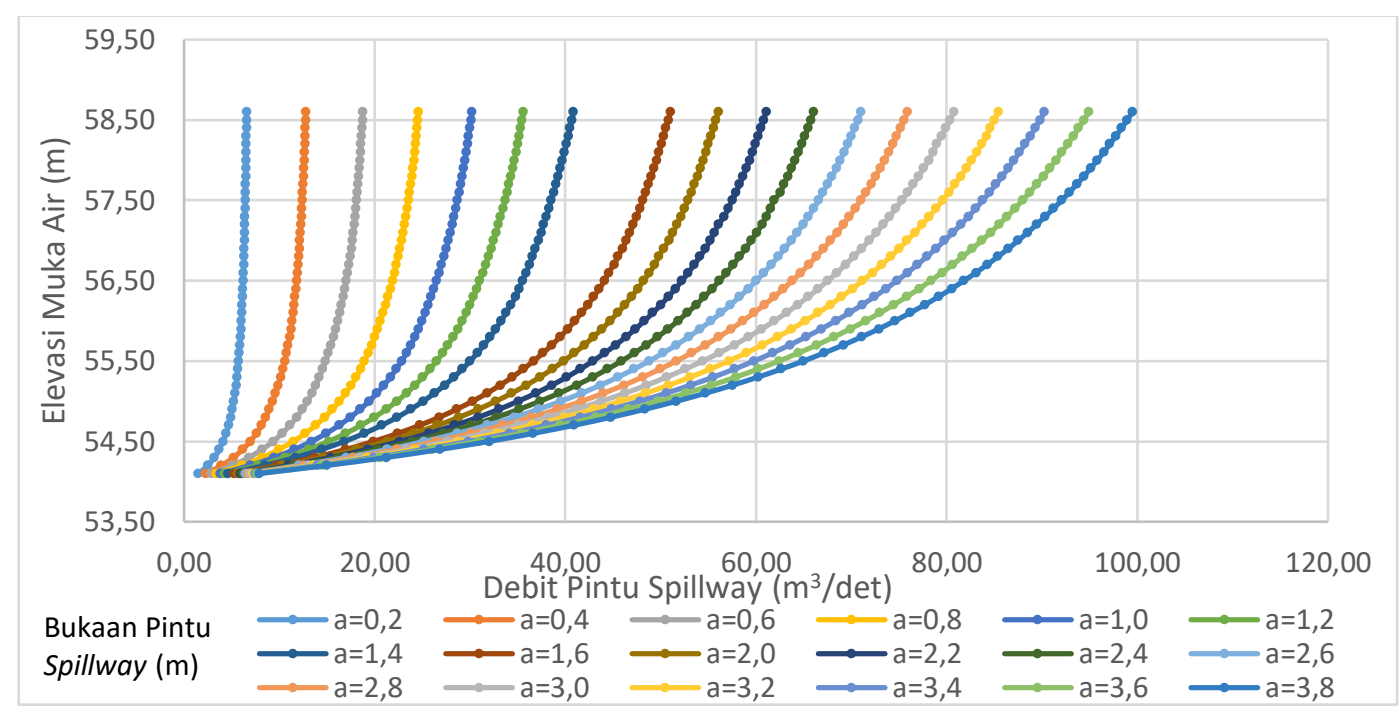

Gambar 6: Grafik Tinggi Muka Air dengan Tinggi Bukaan Pintu Spillway

Dari gambar grafik diatas dapat disimpulkan bahwa kurva membentuk trendline segaris. Dimana tidak ada yang bersebrangan atau bertabrakan. Jadi bisa dikatan bahwa perhitungan debit sesuai dan bisa diaplikasikan pada pintu tegak (sluice gate).

\subsection{Simulasi Pola Operasi Pintu}

Simulasi pola operasi bukaan pintu didasarkan pada tiga kondisi, yaitu kondisi Muka Air Surut/Low Water Level (LWL) pada elevasi +57,2 meter; Muka Air Normal/Normal Water Level (MAN/NWL) pada elevasi +57,3 meter; dan Muka Air Banjir/High Water Level (HWL) pada elevasi $+58,28$ meter. Penetapan dasar acuan dalam perhitungan simulasi pola operasi dikaitkan dengan kebutuhan air irigasi pada kebutuhan irigasi Waru dan kebutuhan irigasi Turi pada Tabel 1 
Tabel 1: Kebutuhan Irigasi Waru dan Turi

\begin{tabular}{|c|c|c|c|c|c|c|c|}
\hline \multicolumn{2}{|c|}{$\begin{array}{c}\text { Q Intake } \\
\text { Irigasi Waru } \\
\text { (Ltr/dtk) }\end{array}$} & \multicolumn{2}{|c|}{$\begin{array}{c}\text { Q Intake } \\
\text { Irigasi waru } \\
\text { (Ltr/dtk) }\end{array}$} & \multicolumn{2}{|c|}{$\begin{array}{c}\text { Q Intake } \\
\text { Irigasi Turi } \\
\text { (Ltr/dtk) } \\
\end{array}$} & \multicolumn{2}{|c|}{$\begin{array}{c}\text { Q Intake } \\
\text { Irigasi Turi } \\
\text { (Ltr/dtk) }\end{array}$} \\
\hline \multirow{4}{*}{ Jan } & 17,56 & & 12,30 & & 18,89 & & 15,22 \\
\hline & 18,00 & Jul & 12,30 & Jan & 18,59 & Jul & 15,22 \\
\hline & 16,91 & & 11,97 & & 17,39 & & 15,22 \\
\hline & 18,00 & & 10,28 & & 18,89 & & 11,19 \\
\hline \multirow{3}{*}{ Feb } & 18,00 & Aug & 9,20 & $\mathrm{Feb}$ & 18,89 & Aug & 13,59 \\
\hline & 16,46 & & 8,96 & & 16,53 & & 11,42 \\
\hline & 17,56 & & 8,96 & & 18,59 & & 12,06 \\
\hline \multirow[t]{3}{*}{ Mar } & 17,56 & Sep & 9,74 & Mar & 18,59 & Sep & 12,06 \\
\hline & 16,76 & & 9,74 & & 16,65 & & 10,85 \\
\hline & 16,66 & & 9,74 & & 15,51 & & 10,27 \\
\hline \multirow[t]{3}{*}{ Apr } & 17,08 & Oct & 9,74 & Apr & 15,66 & Oct & 10,27 \\
\hline & 15,84 & & 9,74 & & 15,12 & & 9,62 \\
\hline & 16,30 & & 10,75 & & 15,19 & & 11,28 \\
\hline \multirow[t]{3}{*}{ May } & 16,12 & Nov & 10,75 & May & 16,72 & Nov & 11,18 \\
\hline & 16,12 & & 14,20 & & 17,68 & & 12,45 \\
\hline & 16,60 & & 16,60 & & 12,01 & & 15,10 \\
\hline \multirow[t]{2}{*}{ Jun } & 15,02 & Dec & 18,00 & Jun & 11,31 & Dec & 15,06 \\
\hline & 13,72 & & 17,10 & & 15,22 & & 10,99 \\
\hline
\end{tabular}

Dengan mengatahui kebutuhan air irigasi tiap periodenya maka dapat dibuat pola operasi bukaan pintu. Pada kondisi normal (ideal) dipakai acuan Muka Air Normal/Normal Water Level (MAN/NWL) pada elevasi +57,3 m.. Pintu intake Waru dan Turi masing-masing berjumlah empat buah. Pintu spillway berjumlah sembilan, namun karena pintu No. 5 tidak dapat berfungsi maka pengoperasian hanya delapan pintu. Pola operasi bukaan pintu mengikuti debit kebutuhan irigasi tiap intake. Berikut merupakan pola operasi bukaan pintu pada pintu intake Waru, intake Turi, dan spillway:

Tabel 2: Pola Opeasi Pintu Intake Waru (+57,3 m)

\begin{tabular}{|c|c|c|c|c|c|c|c|c|c|c|c|c|c|}
\hline & \multirow{2}{*}{$\begin{array}{c}\mathrm{Q} \\
\text { Intake } \\
(\mathrm{m} 3 / \mathrm{s})\end{array}$} & \multirow{2}{*}{$\begin{array}{c}\mathrm{Q} \\
\text { Pintu } \\
(\mathrm{m} 3 / \mathrm{s})\end{array}$} & \multicolumn{4}{|c|}{$\begin{array}{c}\text { Tinggi Bukaan Pintu Empiris } \\
(\mathrm{m})\end{array}$} & & \multirow{2}{*}{$\begin{array}{c}\mathrm{Q} \\
\text { Intake } \\
(\mathrm{m} 3 / \mathrm{s})\end{array}$} & \multirow{2}{*}{$\begin{array}{c}\mathrm{Q} \\
\text { Pintu } \\
(\mathrm{m} 3 / \mathrm{s})\end{array}$} & \multicolumn{4}{|c|}{$\begin{array}{c}\text { Tinggi Bukaan Pintu Empiris } \\
(\mathrm{m})\end{array}$} \\
\hline & & & No.1 & No. 2 & No.3 & No.4 & & & & No.1 & No. 2 & No. 3 & No.4 \\
\hline \multirow{3}{*}{ Jan } & 17,56 & 17,560 & 0,20 & 0,26 & 0,20 & 0,20 & \multirow{3}{*}{ Jul } & 12,30 & 12,300 & 0,20 & 0,20 & 0,20 & 0,00 \\
\hline & 18,00 & 18,000 & 0,20 & 0,28 & 0,20 & 0,20 & & 12,30 & 12,300 & 0,20 & 0,20 & 0,20 & 0,00 \\
\hline & 16,91 & 16,910 & 0,20 & 0,23 & 0,20 & 0,20 & & 11,97 & 11,970 & 0,20 & 0,18 & 0,20 & 0,00 \\
\hline \multirow{3}{*}{ Feb } & 18,00 & 18,000 & 0,20 & 0,28 & 0,20 & 0,20 & \multirow{3}{*}{$\begin{array}{c}\mathrm{Au} \\
\mathrm{g}\end{array}$} & 10,28 & 10,282 & 0,20 & 0,10 & 0,20 & 0,00 \\
\hline & 18,00 & 18,000 & 0,20 & 0,28 & 0,20 & 0,20 & & 9,2 & 9,224 & 0,20 & 0,05 & 0,20 & 0,00 \\
\hline & 16,46 & 16,460 & 0,20 & 0,20 & 0,20 & 0,20 & & 8,96 & 8,960 & 0,20 & 0,04 & 0,20 & 0,00 \\
\hline \multirow{3}{*}{ Mar } & 17,56 & 17,560 & 0,20 & 0,26 & 0,20 & 0,20 & \multirow{3}{*}{ Sep } & 8,96 & 8,960 & 0,20 & 0,04 & 0,20 & 0,00 \\
\hline & 17,56 & 17,560 & 0,20 & 0,26 & 0,20 & 0,20 & & 9,74 & 9,744 & 0,20 & 0,07 & 0,20 & 0,00 \\
\hline & 16,76 & 16,760 & 0,20 & 0,22 & 0,20 & 0,20 & & 9,74 & 9,744 & 0,20 & 0,07 & 0,20 & 0,00 \\
\hline \multirow{3}{*}{ Apr } & 16,66 & 16,660 & 0,20 & 0,21 & 0,20 & 0,20 & \multirow{3}{*}{ Oct } & 9,74 & 9,744 & 0,20 & 0,07 & 0,20 & 0,00 \\
\hline & 17,08 & 17,080 & 0,20 & 0,24 & 0,20 & 0,20 & & 9,74 & 9,744 & 0,20 & 0,07 & 0,20 & 0,00 \\
\hline & 15,84 & 15,840 & 0,20 & 0,17 & 0,20 & 0,20 & & 9,74 & 9,744 & 0,20 & 0,07 & 0,20 & 0,00 \\
\hline \multirow{2}{*}{ Ma } & 16,30 & 16,300 & 0,20 & 0,19 & 0,20 & 0,20 & \multirow{3}{*}{$\begin{array}{c}\text { No } \\
\text { v }\end{array}$} & 10,75 & 10,750 & 0,20 & 0,12 & 0,20 & 0,00 \\
\hline & 16,12 & 16,120 & 0,20 & 0,19 & 0,20 & 0,20 & & 10,75 & 10,750 & 0,20 & 0,12 & 0,20 & 0,00 \\
\hline $\mathrm{y}$ & 16,12 & 16,120 & 0,20 & 0,19 & 0,20 & 0,20 & & 14,20 & 14,205 & 0,20 & 0,09 & 0,20 & 0,20 \\
\hline \multirow{3}{*}{ Jun } & 16,60 & 16,600 & 0,20 & 0,21 & 0,20 & 0,20 & \multirow{3}{*}{ Dec } & 16,60 & 16,600 & 0,20 & 0,21 & 0,20 & 0,20 \\
\hline & 15,02 & 15,020 & 0,20 & 0,13 & 0,20 & 0,20 & & 18,00 & 18,000 & 0,20 & 0,28 & 0,20 & 0,20 \\
\hline & 13,72 & 13,735 & 0,20 & 0,07 & 0,20 & 0,20 & & 17,10 & 17,100 & 0,20 & 0,24 & 0,20 & 0,20 \\
\hline
\end{tabular}


Tabel 3 Pola Opeasi Pintu Intake Turi (+57,3 m)

\begin{tabular}{|c|c|c|c|c|c|c|c|c|c|c|c|c|c|}
\hline & \multirow{2}{*}{$\begin{array}{c}\mathrm{Q} \\
\text { Intake } \\
(\mathrm{m} 3 / \mathrm{s})\end{array}$} & \multirow{2}{*}{$\begin{array}{c}\mathrm{Q} \\
\text { Pintu } \\
(\mathrm{m} 3 / \mathrm{s})\end{array}$} & \multicolumn{4}{|c|}{$\begin{array}{l}\text { Tinggi Bukaan Pintu Empiris } \\
(\mathrm{m})\end{array}$} & & \multirow{2}{*}{$\begin{array}{c}\mathrm{Q} \\
\text { Intake } \\
(\mathrm{m} 3 / \mathrm{s})\end{array}$} & \multirow{2}{*}{$\begin{array}{c}\mathrm{Q} \\
\text { Pintu } \\
(\mathrm{m} 3 / \mathrm{s}) \\
\end{array}$} & \multicolumn{4}{|c|}{$\begin{array}{c}\text { Tinggi Bukaan Pintu Empiris } \\
(\mathrm{m})\end{array}$} \\
\hline & & & No.1 & No. 2 & No.3 & No.4 & & & & No.1 & No. 2 & No.3 & No.4 \\
\hline \multirow{3}{*}{ Jan } & 18,89 & 18,890 & 0,20 & 0,12 & 0,20 & 0,20 & \multirow{3}{*}{ Jul } & 11,15 & 11,161 & 0,20 & 0,02 & 0,20 & 0,00 \\
\hline & 18,59 & 18,590 & 0,20 & 0,11 & 0,20 & 0,20 & & 17,02 & 17,028 & 0,20 & 0,05 & 0,20 & 0,00 \\
\hline & 17,39 & 17,390 & 0,20 & 0,06 & 0,20 & 0,20 & & 17,41 & 17,416 & 0,20 & 0,06 & 0,20 & 0,00 \\
\hline \multirow{3}{*}{ Feb } & 18,59 & 18,590 & 0,20 & 0,11 & 0,20 & 0,20 & \multirow{3}{*}{$\begin{array}{c}\mathrm{Au} \\
\mathrm{g}\end{array}$} & 15,87 & 15,870 & 0,20 & 0,01 & 0,20 & 0,00 \\
\hline & 18,89 & 18,890 & 0,20 & 0,12 & 0,20 & 0,20 & & 15,87 & 15,870 & 0,20 & 0,01 & 0,20 & 0,00 \\
\hline & 16,53 & 16,530 & 0,20 & 0,03 & 0,20 & 0,20 & & 15,87 & 15,870 & 0,20 & 0,01 & 0,20 & 0,00 \\
\hline \multirow{3}{*}{ Mar } & 18,59 & 18,590 & 0,20 & 0,11 & 0,20 & 0,20 & \multirow{3}{*}{ Sep } & 13,32 & 13,320 & 0,20 & 0,11 & 0,20 & 0,00 \\
\hline & 18,59 & 18,590 & 0,20 & 0,11 & 0,20 & 0,20 & & 13,32 & 13,320 & 0,20 & 0,11 & 0,20 & 0,00 \\
\hline & 16,65 & 16,650 & 0,20 & 0,03 & 0,20 & 0,20 & & 10,134 & 10,134 & 0,20 & 0,19 & 0,20 & 0,00 \\
\hline \multirow{3}{*}{ Apr } & 15,51 & 15,510 & 0,20 & 0,19 & 0,20 & 0,20 & \multirow{3}{*}{ Oct } & 10,27 & 10,270 & 0,20 & 0,19 & 0,20 & 0,00 \\
\hline & 15,66 & 15,660 & 0,20 & 0,20 & 0,20 & 0,20 & & 9,62 & 9,620 & 0,20 & 0,17 & 0,20 & 0,00 \\
\hline & 15,12 & 15,120 & 0,20 & 0,18 & 0,20 & 0,20 & & 10,27 & 10,270 & 0,20 & 0,19 & 0,20 & 0,00 \\
\hline \multirow{3}{*}{$\begin{array}{c}\mathrm{Ma} \\
\mathrm{y}\end{array}$} & 15,19 & 15,190 & 0,20 & 0,18 & 0,20 & 0,20 & \multirow{3}{*}{$\begin{array}{c}\text { No } \\
\text { v }\end{array}$} & 11,28 & 11,280 & 0,20 & 0,03 & 0,20 & 0,00 \\
\hline & 16,72 & 16,720 & 0,20 & 0,04 & 0,20 & 0,20 & & 11,28 & 11,280 & 0,20 & 0,03 & 0,20 & 0,00 \\
\hline & 17,68 & 17,680 & 0,20 & 0,07 & 0,20 & 0,20 & & 16,04 & 16,040 & 0,20 & 0,01 & 0,20 & 0,20 \\
\hline \multirow{3}{*}{ Jun } & 14,95 & 14,950 & 0,20 & 0,17 & 0,20 & 0,20 & \multirow{3}{*}{ Dec } & 18,48 & 18,480 & 0,20 & 0,10 & 0,20 & 0,20 \\
\hline & 17,94 & 17,943 & 0,20 & 0,08 & 0,20 & 0,20 & & 18,89 & 18,890 & 0,20 & 0,12 & 0,20 & 0,20 \\
\hline & 16,88 & 16,889 & 0,20 & 0,04 & 0,20 & 0,20 & & 17,55 & 17,555 & 0,20 & 0,07 & 0,20 & 0,20 \\
\hline
\end{tabular}

Tabel 4: Pola Opeasi Pintu Spillway (+57,3 m)

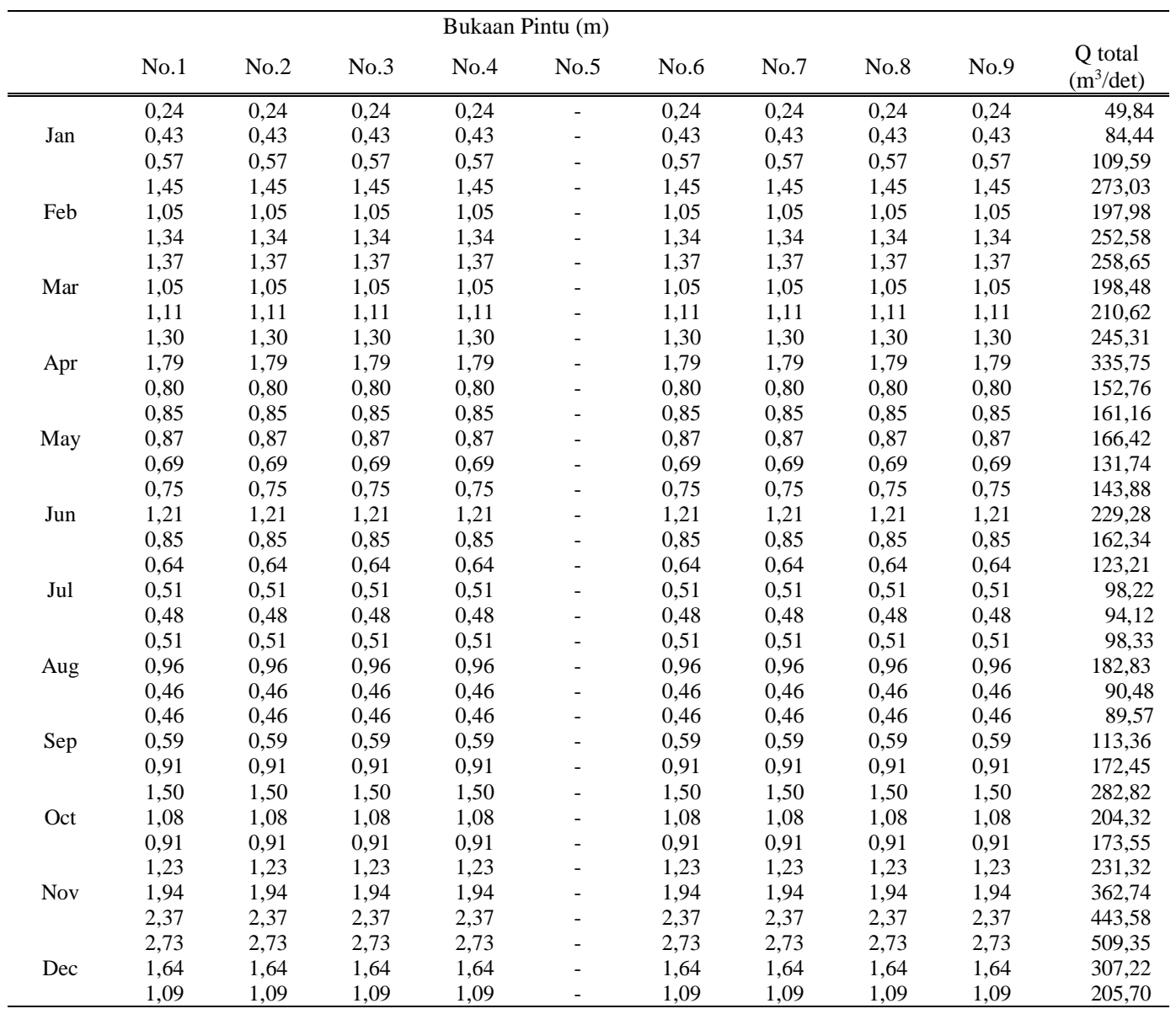




\section{Kesimpulan}

Muka Air Normal (MAN) pada pola operasi bukaan pintu dijadikan acuan dasar karena kondisi tersebut yang diharapkan pada perencanaan awal $(+57,3 \mathrm{~m})$. Dan pada kondisi MAN kebutuhan air dapat terjaga pada hulu dan hilir Bendung. Tetapi jika terjadi kondisi diluar kondisi normal bisa dipakai muka air surut atau muka air banjir.

Berdasarkan analisa perhitungan analitis pada Bendung Gerak Waru Turi (Mrican), Didapatkan pola operasi baru dengan bukaan pintu spillway berjumlah delapan pintu. Pada kondisi MAN (el. $+57,3 \mathrm{~m}$ ) pintu Waru didapatkan bukaan maksimal sebesar 0,3 meter dengan debit $6,211 \mathrm{~m}^{3} / \mathrm{det}$ tiap pintu. Pintu Turi didapatkan maksimal bukaan sebesar 0,3 meter dengan debit 7,936 m³/det tiap pintu. Dan pintu spillway bukaan maksimal terbesar pada 2,73 meter dengan debit $63,67 \mathrm{~m}^{3} / \mathrm{det}$ tiap pintu.

Dengan melihat pada debit yang dikeluarkan dengan debit kebutuhan irigasi, pola operasi bukaan tiap pintu intake maupun spillway dapat memenuhi kebutuhan irigasi Waru dan Turi. Maka, dapat disimpulkan bahwa studi ini dapat dijadikan referensi dalam variasi pola operasi bukaan pintu (ketika fungsi pintu tidak dapat beroperasi maksimal), dengan tetap memperhatikan kebutuhan irigasi tiap intake.

\section{Ucapan Terima kasih}

Penulis mengucapkan terima kasih kepada UPTD Kabupaten Kediri, Perum Jasa Tirta I dan juga ucapan terima kasih kepada seluruh pihak atas dukungan yang telah diberikan.

\section{Daftar Pustaka}

[1] C. Asdak, Hidrologi dan Pengelolaan Aliran Sungai, Yogyakarta: UGM Press, 2014.

[2] M. M. Eman Mawardi, Desain Hidraulik Bendung Tetap untuk Irigasi Teknis, Bandung: Alfabeta, 2002.

[3] M. J. Ismoyo, "Pengaturan Pintu Irigasi Mrican Kanan Dalam Pengoperasian Kebutuhan Air Irigasi," Jurnal Teknik Pengairan, Vols. Vol 1, No 2, pp. 127-135, 2010.

[4] A. t. M. d. G. Ryszard A. Daniel, "Damage and Repair of an Old Weir Gate in the Meuse After a Clamity," PIANC MMX Congress Liverpool UK, pp. 1-15, 2010.

[5] C. D. R. a. J. S. Fatchan Nurrochmad, "Analysis of Intake Gate Operation of the Three Weirs in Bedog River," Engineering International Conference (EIC), vol. Vol 020039, pp. 1-10, 2016.

[6] Anonim, Standar Perencanaan Irigasi Kriteria Perencanaan Bagian Bangunan KP-04, Jakarta: Kementerian Pekerjaan Umum Direktorat Jenderal Sumber Daya Air Direktorat Irigasi dan Rawa, 2013.

[7] Anonim, Manual Operasi dan Pemeliharaan Bendung Mrican (Mrican Barrage), Malang: Perusahaan Umum (Perum) Jasa Tirta I, 2010. 
[8] M. Ghodsian, "Flow through Side Sluice Gate," Journal of Irrigation and Drainage Engineering, vol. Vol. 129, pp. 458-463, 2003.

[9] J. S. Maatooq, "Hydraulic Characteristics and Discharge of Canal Sluice Gate: Practical Approach," University of Baghdad Engineering Journal, vol. Vol. 22, pp. 16-35, 2016.

[10] A. L. Simon, Hydraulics, United States: (Wiley) Prentice Hall College Div, 1996. 